\title{
KRUŽNA RASKRIŽJA - SUVREMENI NAČIN RJEŠAVANJA PROMETA U GRADOVIMA
}

\author{
Ivan Omazić \\ Sveučilište J.J. Strossmayera u Osijeku, Građevinski fakultet Osijek, student \\ Sanja Dimter \\ Sveučilište J.J. Strossmayera u Osijeku, Građevinski fakultet Osijek, doc.dr.sc. \\ Ivana Barišić \\ Sveučilište J.J. Strossmayera u Osijeku, Građevinski fakultet Osijek, dipl.ing.građ.
}

Sažetak: Izgradnja kružnih tokova intenzivirana je posljednjih 20 godina u svim europskim zemljama. U skladu S tim, ovakva raskrižja i u Hrvatskoj dobivaju sve značajniju primjenu. Razlog tomu su brojne prednosti koje kružna raskrižja imaju pred klasičnim raskrižjima. Osnovne karakteristike ovih raskrižja su kanalizirani promet koji se odvija u smjeru suprotnom od kazaljke na satu, mogućnost spajanja 4 i više priključaka te smanjenje broja konfliktnih točaka s obzirom na klasična raskrižja. To rezultira povećanjem sigurnosti i propusne moći, što se ističe i kao njihova najveća prednost. U gradu Osijeku je dosada izgrađeno pet kružnih raskrižja. Kako su se postojeća kružna raskrižja pokazala kao korisna i praktična rješenja, njihov broj bi se u skoroj budućnosti trebao povećati. U radu su opisane osnovne karakteristike kružnih raskrižja te specifičnosti onih izgrađenih na području grada Osijeka.

Ključne riječi: kružna raskrižja, sigurnost, propusnost, grad Osijek

\section{ROUNDABOUTS - MODERN WAY OF DEALING WITH CITY TRAFFIC}

\begin{abstract}
Construction of roundabouts is intensified over the past 20 years in all European countries. Accordingly, those kinds of intersection are becoming more important in Croatia. The reasons for this are numerous advantages of a roundabout over the conventional intersections. Basic characteristics of roundabouts are traffic channelization, the possibility of connecting 4 or more junction roads and reduction of conflict points. This results in improved security and higher intersection capacity as their greatest advantage. There are five roundabouts built in the city of Osijek. As the existing roundabout proved to be useful and practical solutions, their number will increase in the near future. In this paper the basic characteristics of roundabouts and the specifics of roundabouts built in the city of Osijek are presented.
\end{abstract}

Key words: roundabouts, safety, road capacity, city of Osijek 


\section{Uvod}

Prva pojava raskrižja s kružnim tokom (tzv. kružna raskrižja, RKT) kao oblikovno strukturni elementi javili su se početkom XX. stoljeća, mnogo prije dominacije motornog prometa [1]. Prva praktična uporaba kružnog raskrižja bila je na lokalitetu Columbus Circle u New Yorku 1905. godine. Veći značaj ova raskrižja dobivaju tek pedesetih godina prošlog stoljeća, kada je u Velikoj Britaniji uvedeno pravilo da vozila unutar kružnog toka imaju prednost pred nadolazećim vozilima. Taj događaj bio je prekretnica u razvoju kružnih raskrižja.

U Europi tek posljednjih dvadesetak godina počinje intenzivna gradnja kružnih raskrižja. Procjenjuje se da ih je 1999/2000. godine u svijetu bilo oko trideset i pet tisuća, od čega samo u Francuskoj dvanaest tisuća. Europske zemlje koje se ističu po broju izvedenih kružnih raskrižja, osim Francuske, su Nizozemska sa svojih tri i pol tisuće i Velika Britanija. Zemlje kao Švedska, Švicarska, Danska, Finska, Njemačka i Austrija, također vode politiku njihove velike izgradnje.

Uz prisutan sukcesivni prirast, posebno u tranzicijskim zemljama, procjenjuje se da je danas u svijetu izgrađeno preko četrdeset tisuća kružnih raskrižja. Taj prirast možemo osjetiti i u Hrvatskoj, gdje RKT poprimaju sve veću važnost. Ovakav moderan način rješavanja sve većeg prometa u gradovima prikazan je kroz primjere kružnih raskrižja u gradu Osijeku.

\section{Osobine i podjela kružnih raskrižja}

Kružna raskrižja se definiraju kao prometne građevine po kojima je kretanje vozila određeno središnjim kružnim otokom, kružnim kolnikom te privozima s razdjelnim otocima i prometnim znakovima [2].

Posebnosti RKT su puno veća sigurnost prometa (zbog manjeg broja konfliktnih točaka i smanjene brzine kretanja vozila u kružnom toku), uz manje posljedice prometnih nezgoda (bez čelnih i sudara pod pravim kutom). Također je omogućeno kraće čekanje na privozima čime se osigurava kontinuitet vožnje. Kako je ovim raskrižjima omogućeno propuštanje jačih prometnih tokova, dolazi do povećanja propusne moći raskrižja što ih nameće kao dobro rješenje u slučajevima raskrižja s više privoza, ali i mogućnost dobrog uklapanja u okolni prostor. Od negativnih osobina kružnih raskrižja ističe se smanjenje razine prometne sigurnosti povećanjem broja kružnih prometnih trakova, ali i pri većem biciklističkom i pješačkom prometu koji presijecaju jedan ili više privoza raskrižja. Također se navodi kako su ovakva raskrižja nepovoljna u slučaju velikog prometnog toka sa skretanjem ulijevo.

Kružna raskrižja se mogu razvrstati po više mjerila/kriterija [3], a uobičajena je podjela po lokaciji i veličini, po broju privoza i prometnim trakovima, po svrsi ili namjeni i sl. Podjela prema lokaciji i veličini dijeli kružna raskrižja na ona unutar i izvan naselja. Unutar naselja se razlikuju mini, mala i srednje velika kružna raskrižja, dok izvan naselja postoji podjela na srednje velika, srednje velika dvotračna i velika kružna raskrižja. Podjela prema namjeni dijeli ih na raskrižja koja smiruju promet, ograničavaju ga i ona koja služe za postizanje što veće propusne moći uz dostatnu sigurnost prometa. U pogledu broja privoza, kružni tokovi se dijele na one s tri, četiri, pet ili više privoza, a s obzirom na broj prometnih trakova u kružnom kolniku, postoje jednotračna, dvotračna ili višetračna kružna raskrižja.

\section{Kriteriji za izvođenje kružnog raskrižja}

Četiri osnovne skupine općih kriterija [3] koji moraju biti zadovoljeni prilikom razmatranja primjerenosti izvođenja kružnih raskrižja su:

- prostorni

- $\quad$ prometni

- prometno-sigurnosni

- $\quad$ kriteriji propusne moći.

Prostorni kriterij čini kriterij makrolokacije u kojem se razmatra lokacija i položaj kružnog raskrižja u globalnoj cestovnoj mreži nekog područja. Kriterij mikrolokacije razmatra raspoloživost prostora RKT, posebno u urbanim područjima. 
Za prometni kriterij, opravdanost izvedbe RKT proizlazi iz postojanja većeg broja prilaza približno jednakog prometnog opterećenja te na mjestima gdje nisu intenzivni lijevi skretači, a postoji veliki broj desnih skretača. Također ih je opravdano izvoditi na križanjima tipa T, gdje se prilazni promet manjeg obujma nedopustivo dugo ne može uključiti u glavni prometni tok, te na raskrižjima gdje se očekuje veliki budući promet.

Sa stajališta sigurnosti prometa, preporuča se izvedba na mjestima koja su često poprišta nezgoda s teškim posljedicama, na raskrižjima gdje su prisutne prevelike brzine kretanja vozila na glavnom prometnom smjeru i nije sigurno uključivanje vozila sa sporednog prometnog smjera, te na mjestima gdje se uvjeti vožnje znatno mijenjaju.

Na slici 1 predočena je situacija u kružnom raskrižju s 8 konfliktnih točaka (nasuprot 32 konfliktne točke u klasičnom raskrižju). Ono daje više nego 4 puta sigurnije prometno rješenje, budući da je izbjegnuto čak 16 najopasnijih točaka križanja prometnih tokova. Uz ovo su prikazani najčešći tipovi prometnih nezgoda kod kojih su posljedice manje nego kod nezgoda na klasičnim raskrižjima. Nizozemska iskustva [4] potvrđuju smanjenje broja prometnih nezgoda i poginulih u njima, izborom i izvođenjem kružnog raskrižja kao sigurnijeg tipa raskrižja u odnosu na ono klasično.

a) konfliktne točke

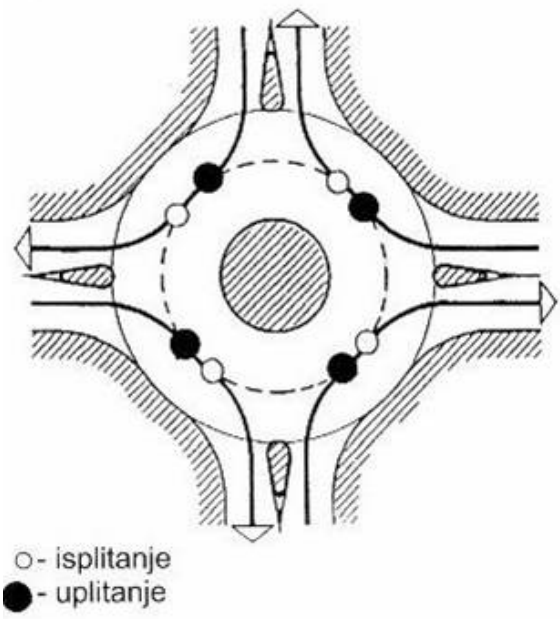

b) tipovi prometnih nesreća

1. pretjecanja pred raskrižjem

2. sudar s pješakom / biciklistom

3. sudar pri uvozu

4. sudar pri preplitanju

5. nalet na vozilo pri uvozu

6. nalet na vozilo pri izvozu

7. udar u središnji otok

8. udar u razdjelni otok pri izvozu

9. izlijetanje s rotora

10. prevrtanje

11. udar u razdjelni otok pri uvozu

12. zanošenje pri izvozu

13. vožnja u pogrešnom smjeru

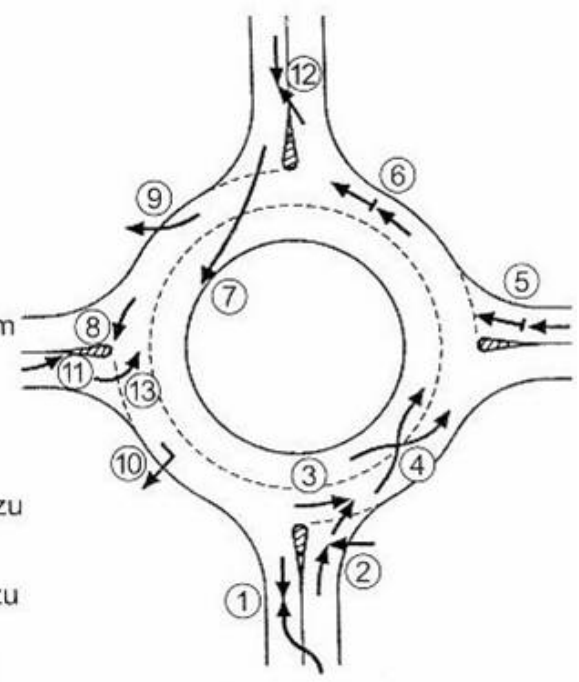

Slika 1 - a) konfliktne točke, b) najčešći tipovi prometnih nesreća

Za svako novo ili rekonstruirano RKT potrebno je provjeriti propusnu moć. Propusna moć ili kapacitet $\left(c_{k}\right)$ izražava broj vozila koji prođe kroz RKT u jedinici vremena, a dobije se zbrajanjem propusnosti $q_{p, n}$ svih privoznih ulaza (n) [3].

Propusnost privoznog ulaza $\left(q_{u}\right)$ određuje broj vozila koji preko njega ulaze u kružno raskrižje $u$ jedinici vremena, dok propusnost jednog ulaznog mjesta izravno ovisi o veličini i svojstvima kružnog toka te 0 geometrijsko-oblikovnim svojstvima cijelog raskrižja. Na slici 2 prikazan je dijagram ovisnosti propusne moći privoza o broju vozila u prometnom toku kružnog raskrižja [2]. Može se zaključiti kako s povećanjem vozila u kružnom toku pada propusna moć privoza. 


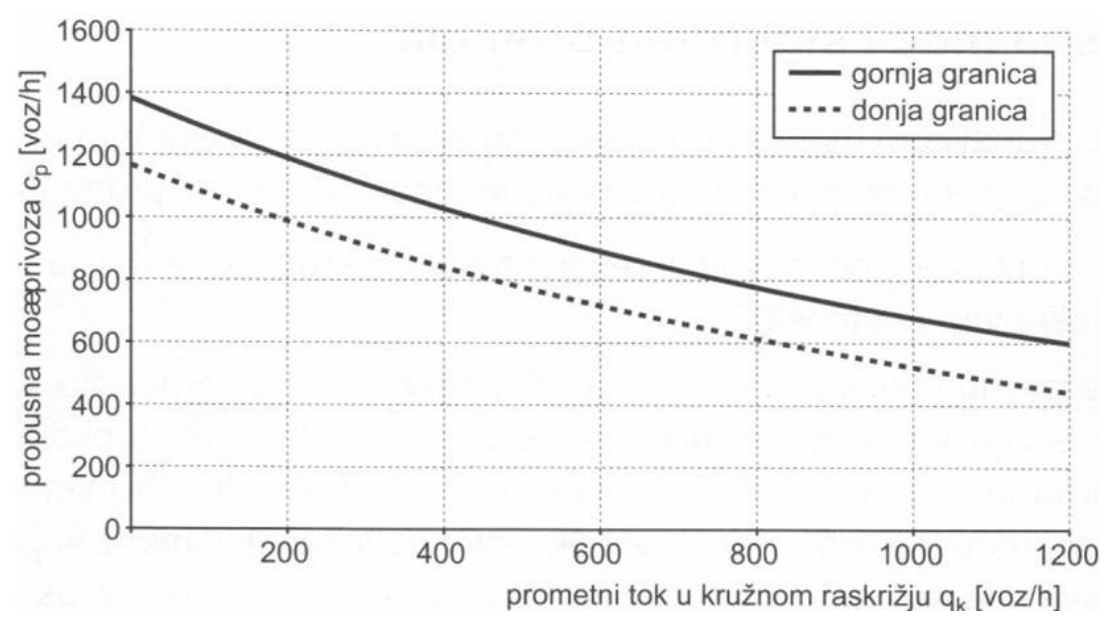

Slika 2 - Dijagram odnosa propusne moći privoza $\left(C_{p}\right)$ i prometa u kružnom raskrižju $\left(q_{k}\right)$

Preuređenjem klasičnog u kružno raskrižje, neophodno je provesti proračun propusne moći za dva ili više vršnih prometnih opterećenja (najčešće jutarnje i popodnevne). Postotak povećanja prometa određuje se kao prosjek posljednjih 5 do 10 godina, a ako nema podataka, koriste se podatci za prosječno povećanje prometa u cijelom području. Na slici 3 prikazana je konverzija broja vozila pri rekonstrukciji klasičnog raskrižja u kružno, potrebna pri proračunu propusne moći.
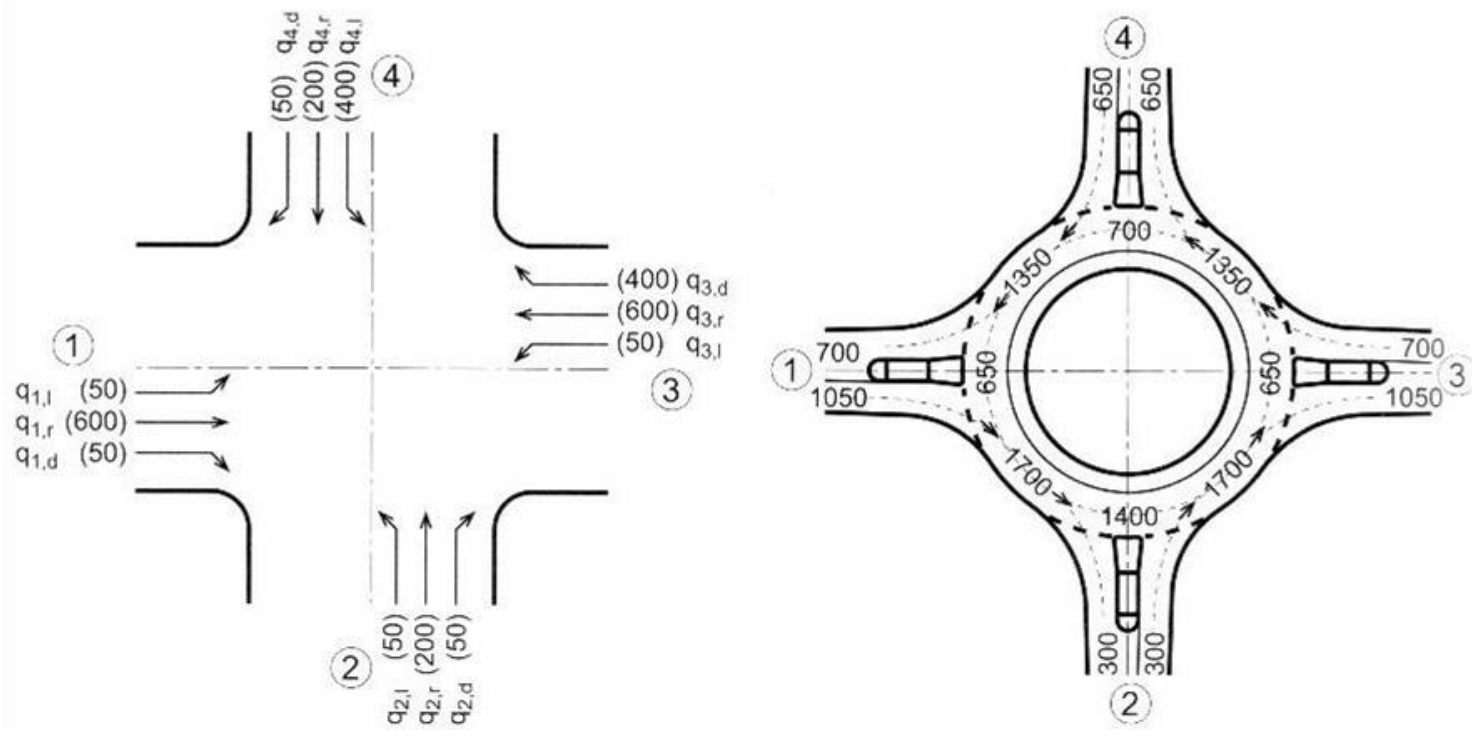

Slika 3 - Konverzija brojenog prometa na klasičnom raskrižju u kružno

Kako Republika Hrvatska još uvijek nema definirane tehničke propise o kružnim raskrižjima i njihovim svojstvima, nije moguća jednoznačna prosudba o njihovoj propusnoj moći i stupnju sigurnosti prometa. Stoga se pri projektiranju i građenju kružnih raskrižja najčešće koriste australske i austrijske (švicarske) metode proračuna propusne moći [5].

Odluka 0 izboru jedne od dviju predlaganih metoda (australska ili austrijska) ovisi o kompleksnosti predviđenoga RKT i/ili raspoloživosti odgovarajućeg računalnog programa. Za mala i srednje velika kružna raskrižja koristi se austrijska metoda proračuna, dok se za velika raskrižja primjenjuje nelinearna australska metoda. Kod ovih se raskrižja dodatno izvodi proračun kašnjenja, broj zaustavljanja i duljine kolona.

Kao važan kriterij prilikom projektiranja nameće se osiguranje preglednosti u kružnom raskrižju. Razlikujemo dvije vrste preglednosti [2]. Prva je preglednost na ulazu u kružno raskrižje i oko središnjeg otoka, dok je druga preglednost pri ostalim prometnim operacijama. Preglednost treba biti osigurana na način da vozač 
(visina oka 1,10 m (kod nas 1,20 m)) uočava prepreku visine 1,10 m, a pregledno polje mora dosezati do visine 2,0 m iznad kolnika (slika 4). Stoga, prometni znakovi na području preglednosti ne smiju biti postavljeni niže od 2,0 m, mjereno od kolnika do donjeg ruba znaka.
a) preglednost ulijevo
b) preglednost pri drugim operacijama

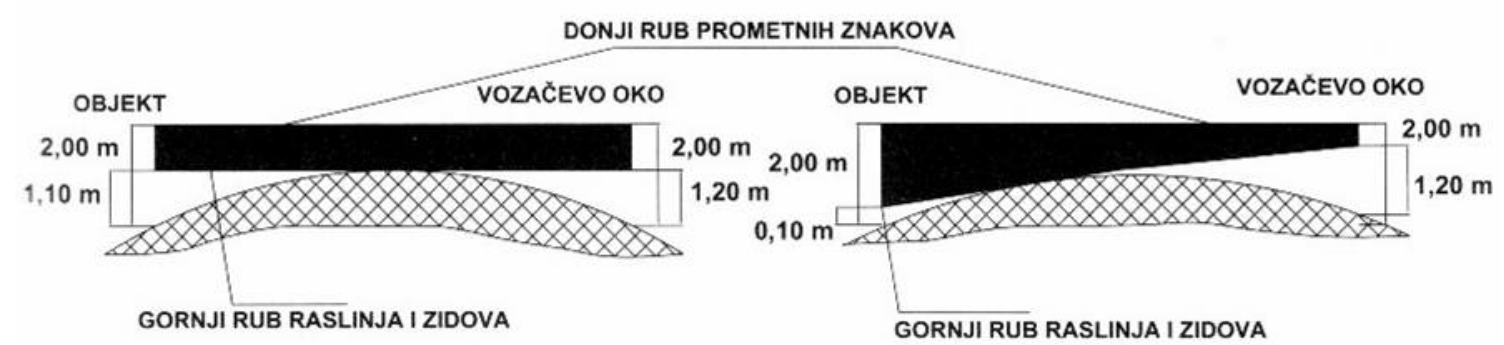

Slika 4 - Preglednost na ulazu u kružno raskrižje i pri ostalim prometnim operacijama

\section{Projektno-oblikovni elementi rotora}

Projektiranje RKT izvodi se u nekoliko glavnih koraka, odabirom:

- $\quad$ vanjskog promjera, tj. polumjera raskrižja $\left(D_{v}, R_{v}\right)$

- $\quad$ širine kružnog kolnika (B)

- S šrine ulaznog i izlaznog dijela privoza $\left(b_{u}, b_{i}\right)$

- širine otoka ili razdjelnika u privozu ( $\left.b_{0}\right)$

- ulaznog kuta $(\varphi)$

- $\quad$ polumjera ulaznog i izlaznog zaobljenja $\left(R_{u}, R_{i}\right)$

- horizontalnog i visinskog vođenja kružnog raskrižja

- poprečnog nagiba kružnog traka i odvodnje, itd. (slika 5)

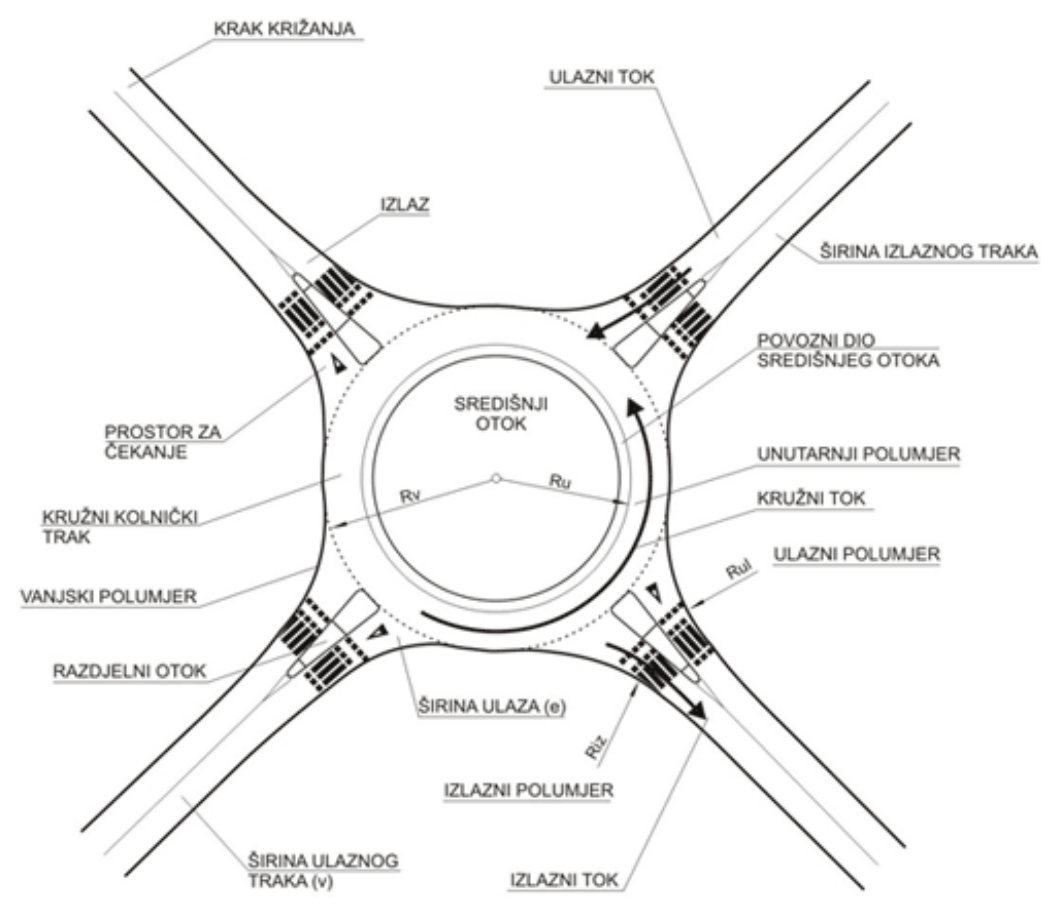

Slika 5 - Osnovni elementi kružnog raskrižja 


\subsection{Kružni kolnik}

Glavni dijelovi kružnog kolnika su vanjski i unutarnji promjer $\left(R_{v}\right)$ / polumjer $\left(R_{u}\right)$, točnije širina kružnog kolnika $(B)$ s jednim ili više prometnih trakova.

Za svako kružno raskrižje potrebno je provjeriti provoznost kružnog kolnika prema mjerodavnom vozilu, posebno pri projektiranju malih kružnih raskrižja u urbanim sredinama kojima prometuju autobusne linije gradskog prijevoza [3].
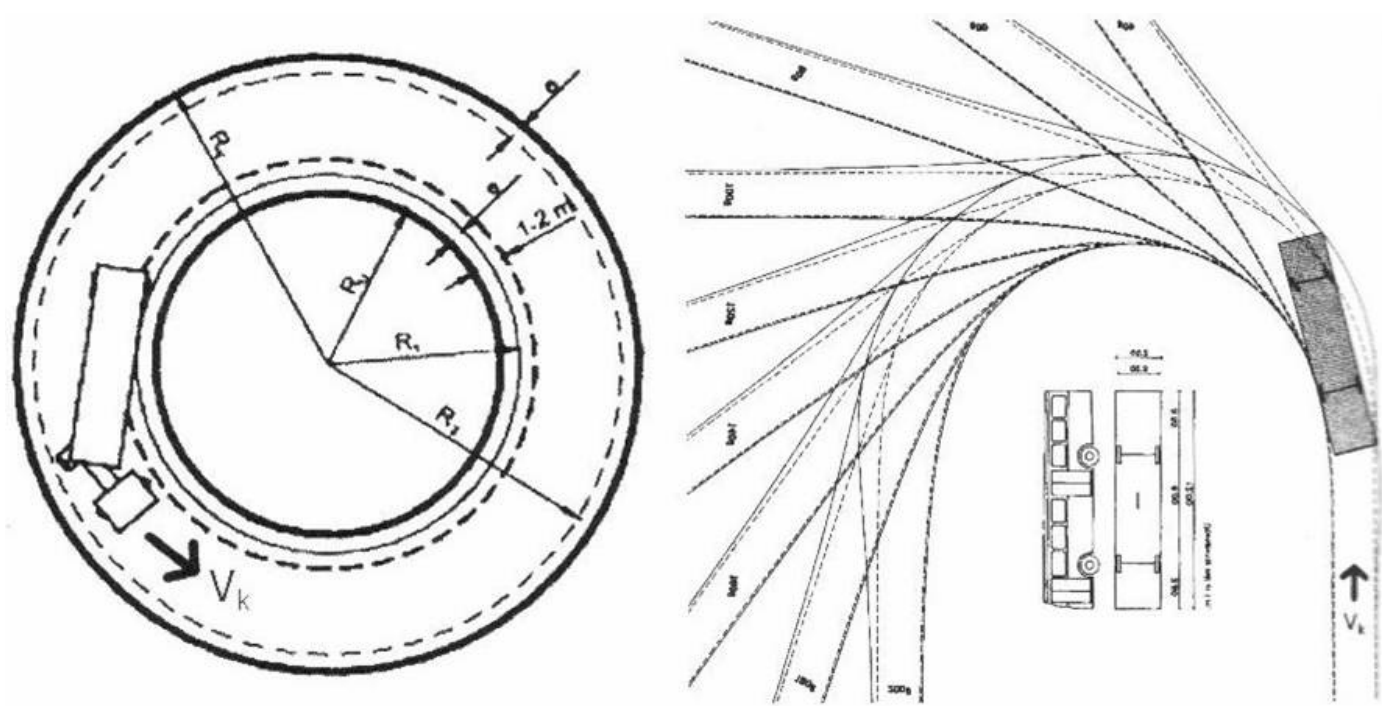

\section{Slika 6 - Elementi za provjeru provoznosti kružnog kolnika i privoza}

Poprečni nagib kružnog kolnika izvodi se u iznosu $q_{\min }=2,5 \%$ prema vanjskoj strani iz više razloga:

- učinkovitije i tehnički prihvatljivije odvodnje

- $\quad$ pogodnijeg prelaska iz privoza u kružni tok

- $\quad$ prisiljavanja na smanjenje brzine u kružnom toku.

Poprečni (q) i uzdužni (s) nagibi te svi detalji prijelomnih ploha u području raskrižja trebaju biti tako oblikovani kako bi se omogućila učinkovita i brza odvodnja te blaga promjena nagiba na prijelazima između priključnog traka i kružnog kolnika. Pri oblikovanju svih površina raskrižja potrebno je osigurati kvalitetnu odvodnju izvodeći poprečne nagibe $\geq 2,5 \%$.

Središnji kružni otok bi trebao u oblikovnom i funkcionalnom pogledu ispuniti bitne kriterije, kao što su:

- omogućavanje prepoznavanja kružnog raskrižja u prometnoj mreži

- naglašavanje prekida trase sa svojstvima slobodnog toka

- omogućavanje obilaženja vozila (ako je izveden kao provozan)

- osiguravanje mjesta za postavljanje prometnih znakova

- osiguravanje prostora za posebna oblikovanja i krajobrazna uređenja.

Prijelazni prsten ima širinu od 1,5 do $2,0 \mathrm{~m}$, a nalazi se između kružnog kolnika i središnjeg otoka, omogućavajući lakši prolaz duljih vozila. Izvodi se od različitog materijala (npr. betonskih elemenata) i/lii u drugoj boji nasuprotnoj boji kolnika, te u poprečnom nagibu oko 4,0\%. Razgraničenje s provoznim dijelom središnjeg otoka treba predvidjeti uz pomoć izdignutih rubnjaka visine $12-14 \mathrm{~cm}$.

\subsection{Privozi}

Jedan od najosjetljivijh postupaka kojim se bitno utječe na sigurnost i propusnu moć kružnog raskrižja je izbor projektnih elemenata i detalja oblikovanja privoza. Pritom je potrebno razlikovati i zasebno dimenzionirati ulazni, odnosno izlazni dio privoza. U ulaznom dijelu puna pozornost se mora posvetiti širini ulaza (e') i duljini proširenja ulaza (l'). Priključni kolnik privoza u pravilu treba biti položen okomito na kružni kolnik, tj. radijalno usmjeren 
prema središtu raskrižja. Ovakvo oblikovanje ulaza privoza bitno je radi povećanja sigurnosti prometa te iz istog razloga ta pravila vrijede i pri projektiranju izlaza iz kružnog raskrižja (slika 7).

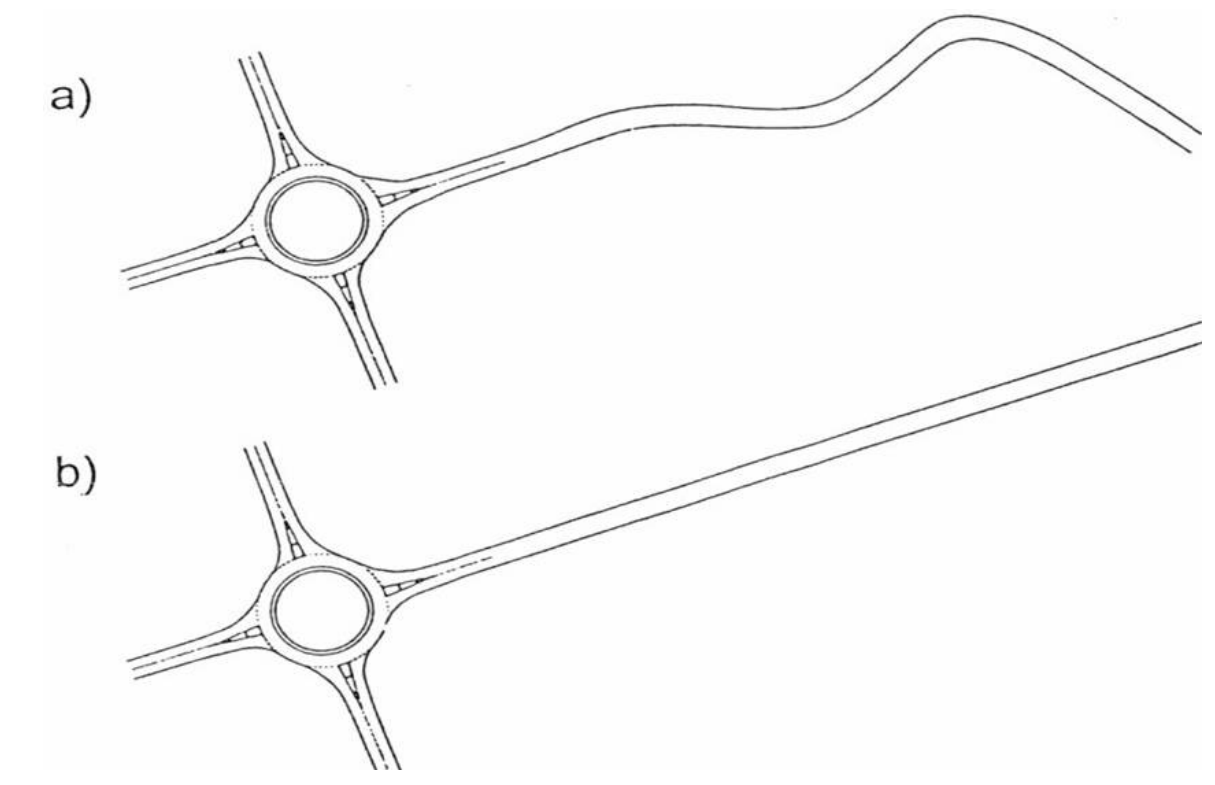

Slika 7 - Tok prilazne ceste a) primjena izvan naselja b) u urbanim sredinama

Privozi mogu biti različito orijentirani međusobno, ali i prema središtu kružnog raskrižja. Sa stanovišta sigurnosti, najpoželjniji položaj privoza je takav u kojem se produžetci privoza sijeku u samo jednoj točki te ako je to sjecište u središtu kružnog raskrižja. Nešto lošija situacija je sjecište lijevo od središta, budući da se tada javljaju velike brzine na izlazu iz raskrižja. Najlošija je situacija ona kada je sjecište desno od središta, jer se time povećava najveća moguća brzina na ulazu u kružni tok prometa.

Razdjelni otoci moraju biti prilagođeni veličini RKT i brzini na ulazu u kružni tok prometa. Preporučljivo je da se na velikim kružnim raskrižjima koriste otoci oblika lijevka, a na malima trokutastog oblika (slika 8). U projektno-oblikovnom pogledu, razdjelne otoke treba postaviti okomito na kružni kolnik, a najmanja širina ne smije biti ispod 1,60 m. Za slučaj prijelaza pješaka, razdjelni otok mora imati širinu minimalno 2,00 m, tj. za bicikliste minimalno $2,50 \mathrm{~m}$.

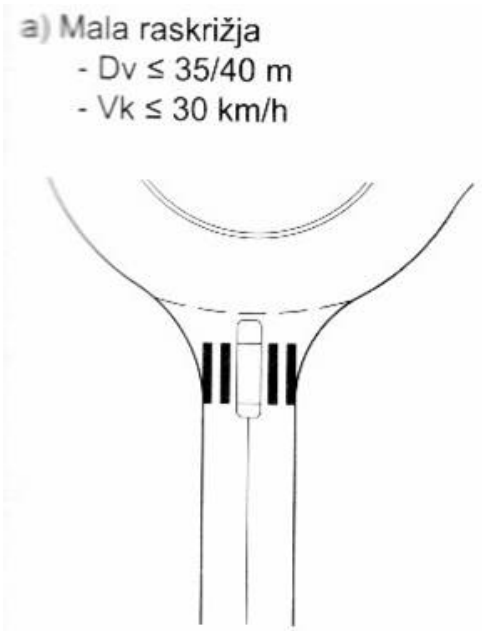
b) Srednja raskrižja
- Dv $\leq 90 \mathrm{~m}$
$-\mathrm{Vk} \leq 35 \mathrm{~km} / \mathrm{h}$
c) Velika raskrižja
- Dv $\geq 90 \mathrm{~m}$
$-\mathrm{Vk} \leq 40 \mathrm{~km} / \mathrm{h}$
Slika 8 - Oblici razdjelnih otoka, ovisno o veličini $\left(D_{v}\right)$ i brzini uvoženja (Vk) a) paralelni b) trokutasti i c) ljevkasti




\section{Oprema i uređenje kružnog raskrižja}

Opremu raskrižja u širem smislu bi mogli podijeliti na:

- $\quad$ prometne znakove, signalizaciju i opremu na cestama

- rasvjetu

- $\quad$ krajobrazno uređenje i ostalu opremu.

Kod prometnih znakova, oblikovna svojstva i prometni režim moraju biti dobro usklađeni kako bi se na raskrižju ostvario najviši stupanj propusnosti i sigurnosti prometa (slika 9). Prometna oprema raskrižja pritom najizravnije utječe na sigurnost i propusnu moć.

Prometne oznake ispred i unutar kružnog raskrižja imaju ulogu reguliranja i naznačivanja:

- $\quad$ umirivanja prometnog toka

- $\quad$ pripreme za kružni tok

- $\quad$ pravovremene pripreme za usmjeravanje na izlaz iz kružnog toka.

$\mathrm{Na}$ unutarnjem dijelu razdjelnog otoka postavljaju se oznake lokaliteta (informacijske ploče) i putokazi. Ispred raskrižja, u području približavanja, postavljaju se obavijesne oznake i znakovi naredbe:

- ograničenje brzine

- prethodna ploča s najavom kružnog toka

- oznaka pješačke ili biciklističke staze i ostale oznake.
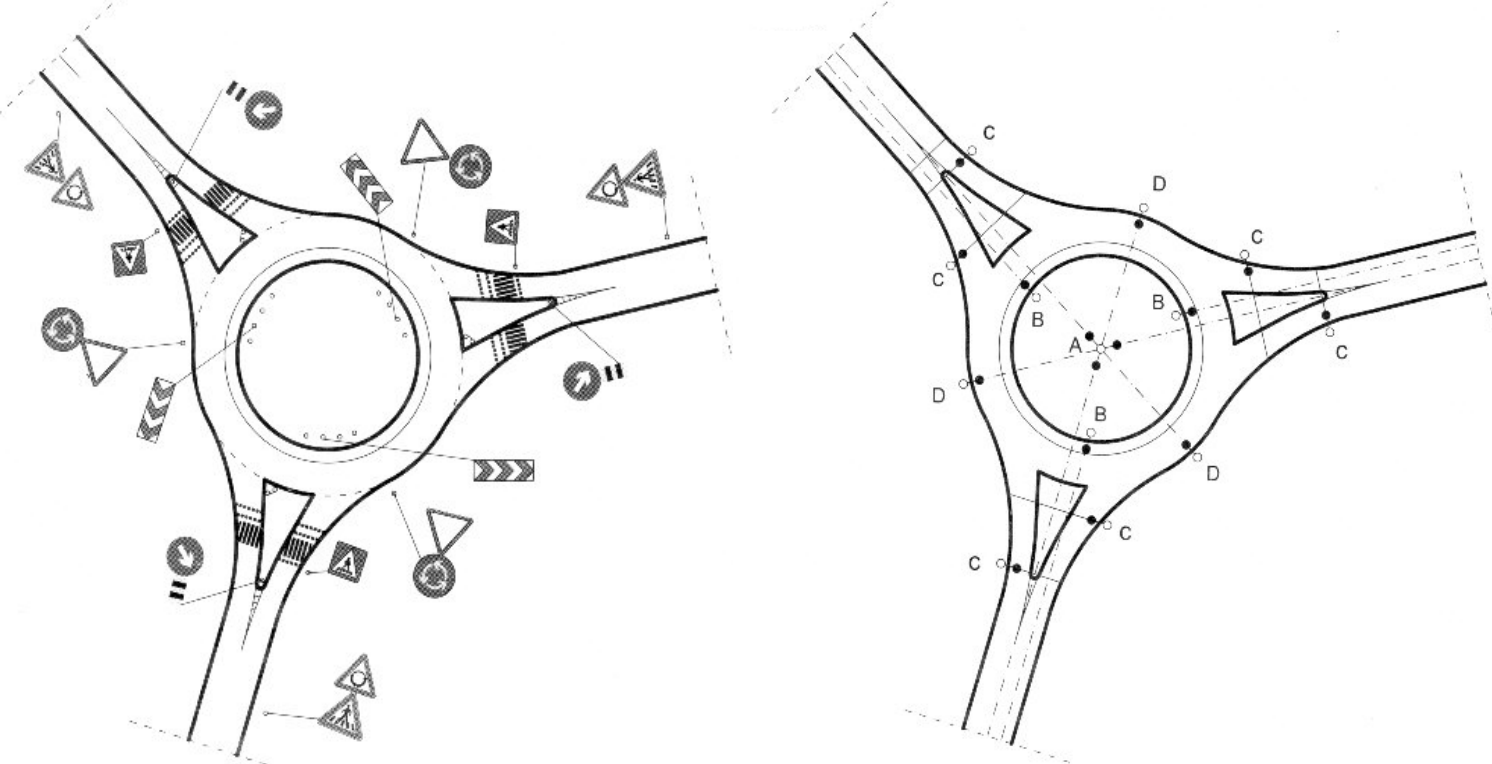

Slika 9 - Dispozicija prometnih znakova i rasvjetnih tijela u kružnom raskrižju

Rasvjeta RKT služi kako bi se zadovoljili uvjeti prometne sigurnosti noću, a razdjelni otoci su dobro mjesto za smještanje stupova javne rasvjete samo ako su dovoljno veliki i ako time ne smanjuju preglednost. Osnovna zadaća rasvjete je dostatno osvjetljenje prometne površine noću i u posebnim vremenskim prilikama, a osnovni elementi rasvjete RKT prikazani su na slici 9. Svaki priključak treba biti osvijetljen barem $60 \mathrm{~m}$ ispred raskrižja, boja svjetlosti i visina svjetiljki mora biti ista na cijelom području raskrižja, a osvijetljenost raskrižja treba biti najmanje jednaka osvijetljenosti priključaka [3].

Kod izgradnje središnjeg otoka treba voditi računa i o njegovu uređenju te uklapanju u okoliš. Tako se uređenje središnjeg otoka u ruralnim krajevima svodi na sadnju autohtone vegetacije i na uređenje zemljišta, dok je u urbanim sredinama poželjno postavljanje sadržaja za podizanje ambijentalne vrijednosti (fontana, ukrasnih stupova, skulptura), pod uvjetom da ne narušavaju prometnu signalizaciju i ukupnu preglednost. 


\section{Kružna raskrižja grada Osijeka}

U gradu Osijeku je u razdoblju od 1995. godine, kada je izrađen prvi projekt kružnog raskrižja (raskrižje "Đakovština") do danas, izgrađeno pet RKT čiji položaj je prikazan na slici 10. Svako od tih raskrižja bit će detaljnije opisano u nastavku [6].

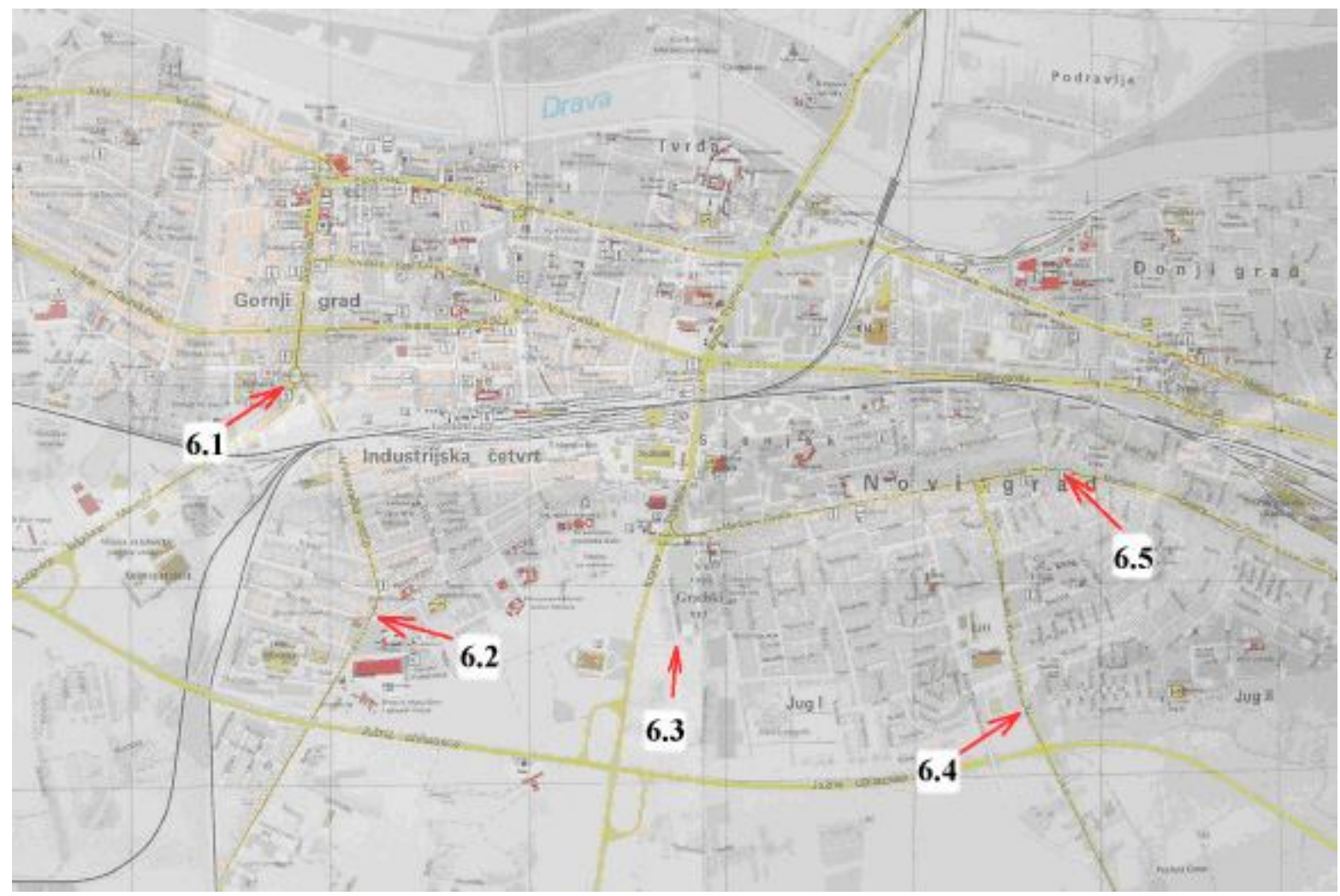

Slika 10 - Položaj kružnih raskrižja u gradu Osijeku

\subsection{Kružno raskrižje "ĐAKOVŠTINA", RKT (n=5)}

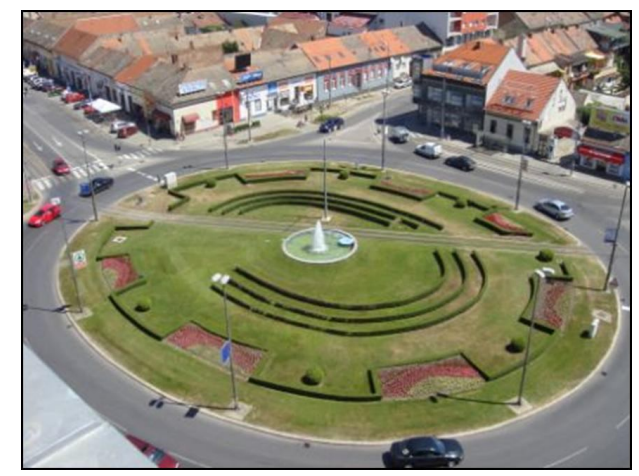

Slika 11 - Kružno raskrižje "ĐAKOVŠTINA"

Položaj i uloga u cestovnoj mreži - Kružni tok se nalazi u blizini samog centra grada Osijeka, na križanju Vinkovačke, Županijske, Reisnerove i Ulice Sv. Leopolda B. Mandića. Predstavlja najveće i najstarije osječko kružno raskrižje, a izgrađen je s ciljem postizanja veće propusne moći uz dostatnu sigurnost prometa. Sastoji se od 5 privoznica te njime prometuje prigradski i gradski promet (slika 11). 
Oblik i sustav raskrižja - Ovo raskrižje pripada kategoriji srednje velikih dvotračnih RKT. Oblika je elipse s vanjskim, većim promjerom od $\mathrm{Dv}_{1}=72$ metra i manjim promjerom od $\mathrm{Dv}_{2}=63,5$ metra. Njihov odnos je 1,13 , što se uklapa u projektnu preporuku o odnosu dijametara do 1,15, proizašlu iz zahtjeva homogenih dinamičkih uvjeta raskrižja [5]. Sadrži dva kružna prometna traka, svaki širine $4 \mathrm{~m}$. Dva od pet privoza imaju po dva prometna traka. Širina jednotračnih privoza je $5 \mathrm{~m}$, a dvotračnih (2 privoza su dvotračna) $7,5 \mathrm{~m}$.

Općenito - Zbog velikog promjera i dva kružna prometna traka izostavljen je prijelazni prsten, dok je središnji otok provozan samo za javni gradski promet. Oblikovni elementi ograničavaju brzinu kretanja vozila u kružnom toku prometa na $40 \mathrm{~km} / \mathrm{h}$. Na svakom privozu izvedeni su trokutasti razdjelni otoci. Poprečni nagib kolnika je dvostrani te su slivnici smješteni na unutarnjem i vanjskom rubu kružnog kolnika. Pješački promet se vodi izvan kružnog kolnika, a prijelazi su pregledni u svako doba dana i noći zahvaljujući dobro postavljenoj rasvjeti. Kružni otok je hortikulturno uređen, a u njegovom središtu se nalazi fontana koja podiže ambijentalnu vrijednost raskrižja.

\subsection{Kružno raskrižje "BOSUTSKO", RKT (n=4)}

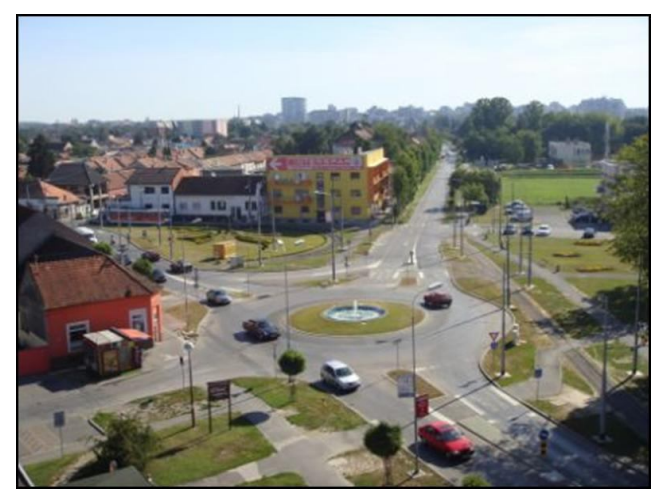

\section{Slika 12 - Kružno raskrižje "BOSUTSKO"}

Položaj i uloga u cestovnoj mreži - Kružni tok se nalazi nešto južnije $(\approx 1,5 \mathrm{~km})$ od najvećeg kružnog raskrižja "Đakovštine", na križanju Vinkovačke, Drinske i Bosutske ulice. Sastoji se od 4 privoznice (slika 12). Njime prometuje pretežito prigradski i gradski promet. Cilj izvedbe ovoga raskrižja također je bilo postizanje veće propusne moći postojećeg raskrižja, uz dostatnu sigurnost prometa.

Oblik i sustav raskrižja - Raskrižje ima oblik malog jednotračnog kružnog raskrižja s vanjskim promjerom Dv=30 metara. Kružni prometni trak je širine 6 metara, a središnji razdjelni otok je promjera Ds=16 metara s prijelaznim prstenom širine 2 metra. Sva četiri privoza imaju ulaze s jednim prometnim trakom širine 2,50-4,0 metra. Privoznica iz Drinske ulice ima izravan odvojak za desno skretanje u Vinkovačku ulicu.

Općenito - Potreba za izvedbom prijelaznog prstena javila se zbog malog promjera i jednog kružnog prometnog traka. Kako bi bio uočljiviji vozačima, izveden je od betonskih elemenata. Središnji otok nije provozan te je uređen i u njegovom središtu se nalazi fontana. Tramvajski promet, za razliku od prethodnog kružnog toka, ne prolazi središnjim otokom, već je smješten između kružnog kolnika i pješačke staze. Oblikovni elementi omogućuju brzine do $30 \mathrm{~km} / \mathrm{h}$. Na svakom od privoza su izvedeni paralelni razdjelni otoci. Poprečni nagib kružnog traka izveden je suprotno središtu raskrižja kao jednostrani nagib te su slivnici smješteni na vanjskom rubu kružnog kolnika. Pješački promet se vodi izvan kružnog kolnika uz pregledne prijelaze. 


\subsection{Kružno raskrižje "DVORANA GRADSKI VRT", RKT (n=3)}

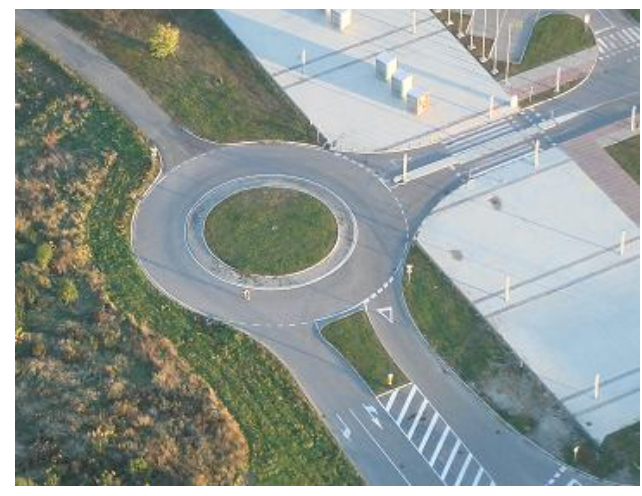

\section{Slika 13 - Kružno raskrižje "DVORANA GRADSKI VRT"}

Položaj i uloga u cestovnoj mreži - Kružni tok se nalazi uz dvoranu "Gradski vrt", uz Trpimirovu ulicu. Izgrađen je u sklopu projekta sportske dvorane, na križanju ulica Stadionsko Naselje i pristupne ceste koja vodi do parkirališta dvorane. Sastoji se od 3 privoznice, a njime se najčešće prometuje za potrebe dvorane i stanovnika navedene ulice (slika 13).

Oblik i sustav raskrižja - Raskrižje pripada kategoriji srednje velikog kružnog raskrižja s jednim kružnim trakom. Vanjski promjer mu iznosi Dv=36 metara, središnji razdjelni otok je promjera Ds=22 metra, a kružni prometni trak je širine 7 metara. Sva tri privoza imaju ulaze s jednim prometnim trakom od kojeg je najveći širine 5 metara.

Općenito - Prijelazni prsten je izveden u širini 2 metra. Središnji otok nije provozan, a niti posebno hortikulturno uređen. Oblikovni elementi omogućuju brzine do $30 \mathrm{~km} / \mathrm{h}$. Na jednom od privoza je izveden paralelni razdjelni otok za prelazak pješaka. Poprečni nagib kružnog traka izveden je nasuprotno središtu raskrižja kao jednostrani nagib te su slivnici smješteni na vanjskom rubu kružnog kolnika. Staze za pješački i biciklistički promet nisu izvedene, a zbog nepostojanja rasvjete noću dolazi do smanjenja preglednosti i sigurnosti prometa i cestovnih vozila. Funkcionalna razina ovog raskrižja se mijenja, ovisno o sadržaju događaja koji se odvijaju u dvorani.

\subsection{Kružno raskrižje "JUG", RKT (n=4)}

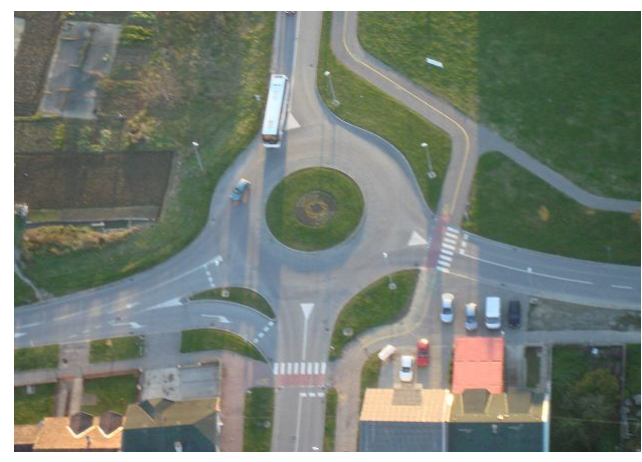

Slika 14 - Kružno raskrižje " JUG "

Položaj i uloga u cestovnoj mreži - ovo kružno raskrižje se nalazi na jugu grada, u blizini sportske dvorane "Jug", na križanju Opatijske ulice i Ulice Josipa Reihl-Kira. Sastoji se od 4 privoznice, a njima prometuje pretežito prigradski i gradski promet (slika 14). Kao i kod ostalih kružnih raskrižja, cilj izvedbe je bilo postizanje veće propusne moći uz dostatnu sigurnost prometa

Oblik i sustav raskrižja - Raskrižje ima oblik malog jednotračnog RKT s vanjskim promjerom Dv=32 metra, središnji razdjelni otok je promjera Ds=20 metara, dok je kružni prometni trak širine 6 metara. Sva četiri privoza 
imaju ulaze s jednim prometnim trakom širine 3,50 metra, s time da privoznica iz Kirove ulice (prometni trak u smjeru grada) ima izravan odvojak za desno skretanje u Opatijsku ulicu.

Općenito - Kao i kod prethodnog raskrižja, zbog malog promjera i jednog kružnog prometnog traka izveden je od betonskih elemenata prijelazni prsten širine 2 metra. Središnji otok nije provozan i prikladno je uređen. Oblikovni elementi omogućuju brzine do ograničenih $30 \mathrm{~km} / \mathrm{h}$. Na privozima nisu izvedeni razdjelni otoci, već su na pojedinim mjestima samo označeni horizontalnom signalizacijom. Poprečni nagib kružnog traka izveden je također nasuprotno središtu raskrižja kao jednostrani nagib, a slivnici su i u ovom raskrižju smješteni uz vanjski rub kružnog kolnika. Pješački i biciklistički promet se vodi izvan kružnog kolnika uz pregledne prijelaze.

\subsection{Kružno raskrižje "DIVALTOVA", RKT (n=5)}

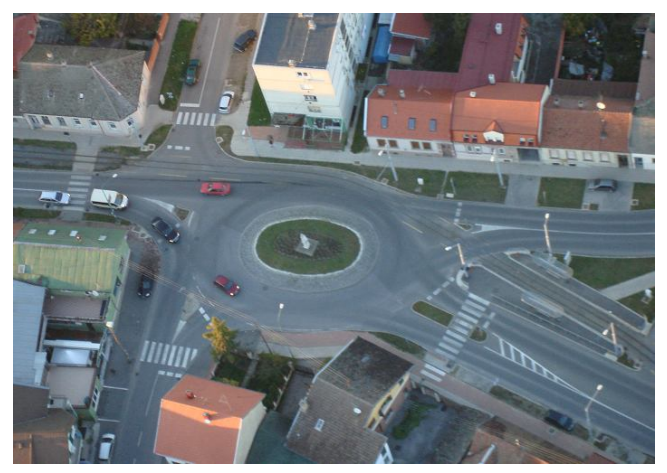

\section{Slika 15 - Kružno raskrižje "DIVALTOVA"}

Položaj i uloga u cestovnoj mreži - Kružni tok se nalazi na križanju Divaltove, Srijemske i Hutlerove ulice. Sastoji se od 5 privoznica (slika 15), s time da se iz sjevernog djela Srijemske ulice ne može ulaziti u kružni tok, već samo iz njega izlaziti. Njime prometuje pretežito prigradski i gradski promet.

Oblik i sustav raskrižja - Raskrižje pripada kategoriji malih jednotračnih RKT. Specifično je po svom izraženom eliptičnom obliku pa tako veći vanjski promjer iznosi Dv=42 metra, a manji 24 metra. Njihov odnos je 1,74, što ukazuje na nehomogene dinamičke uvjete [5]. Razlog takvom rješenju su nepovoljni rubni prostorni uvjeti. Kružni prometni trak je širine $5,75 \mathrm{~m}$. Sva četiri privoza imaju ulaze s jednim prometnim trakom širine 3,0$3,20 \mathrm{~m}$. Privoznica iz istočnog dijela Divaltove ulice ima izravan odvojak za desno skretanje u Hutlerovu ulicu.

Općenito - Na ovom kružnom raskrižju izveden je prijelazni prsten od male kamene kocke uzdignute od razine kolnika rubnjakom. Središnji otok je uzdignut, hortikulturno uređen, s ukrasnim kipom Sv. Florijana u središtu; nije provozan. Tramvajski promet prolazi jednim djelom kružnog kolnika čime smanjuje propusnu moć i sigurnost prometa. Oblikovni elementi omogućuju brzine do $35 \mathrm{~km} / \mathrm{h}$. Na jednom od privoza je izveden paralelni razdjelni otok širine 2,20 metara. Poprečni nagib kružnog traka izveden je nasuprotno središtu raskrižja kao jednostrani nagib te su slivnici smješteni uz vanjski rub kružnog kolnika. Pješački i biciklistički promet se vodi izvan kružnog kolnika, s uređenim i preglednim prijelazima.

\section{Zaključak}

Raskrižja s kružnim tokom su sigurnija i pružaju veću propusnu moć u odnosu na klasična raskrižja. Pored toga, estetski su vrlo pogodna za gradske sredine, s brojnim mogućnostima uređenja središnjeg otoka. S obzirom na brojna pozitivna iskustva izgradnje kružnih raskrižja te njihovih prednosti u odnosu na klasična raskrižja, za očekivati je da će se u Hrvatskoj njihova izgradnja i dalje intenzivirati. Posebno uvažavajući činjenicu da je na našim cestama sve veći broj vozila, a da propusna moć postojećih raskrižja, pogotovo u gradskim sredinama, postaje nedostatna. 


\section{Literatura}

[1] Tollazzi, T. 2000: Krožna križišča, Sveučilišni udžbenik Fakulteta za gradbeništvo, Maribor

[2] Legac, I. 2008: Raskrižja javnih cesta (Cestovne prometnice II.), Zagreb.

[3] Institut prometa i veza 2002: Smjernice za projektiranje i opremanje raskrižja kružnog oblika-rotora, Zagreb

[4] Kenjić, Z. 2009: Kružne raskrsnice- rotori, Priručnik za planiranje i projektiranje, Sarajevo

[5] Ištoka Otković, I. 2008: Modeliranje kapaciteta kružnih raskrižja u Osijeku, Tehnički vjesnik 15(3): 41-47.

[6] Omazić, I. 2009: Raskrižja s kružnim tokom, završni rad, Građevinski fakultet Sveučilišta Josipa Jurja Strossmayera, Osijek 